\title{
The influence of chromone based hydrazones on lipid peroxidation and bFGF concentration in the HL-60 cell line
}

\author{
Andrzej Łazarenkow ${ }^{1}$, Marta Michalska ${ }^{2}$, Anna Gorąca ${ }^{3}$, Marek Mirowski², \\ Jolanta Nawrot-Modranka ${ }^{1}$ and Aleksandra Piechota-Polanczyk ${ }^{3}$
}

'Department of Bioinorganic Chemistry, Chair of Medicinal Chemistry, Faculty of Pharmacy, 2Department of Pharmaceutical Biochemistry, Faculty of Pharmacy, ${ }^{3}$ Department of Cardiovascular Physiology, Medical University of Lodz, Łódź, Poland; Faculty of Pharmacy, Medical University of Lodz, Łódź, Poland; Department of Cardiovascular Physiology, Medical University of Lodz, Łódź, Poland

\begin{abstract}
Natural and synthetic derivatives of benzo-p-pyrones (i.e. flavones, chromones, and coumarins) and their synthetic analogues possess a wide range of biological properties in vitro and in vivo. In this paper we investigated the influence of two hydrazone compounds of chromones, 3-\{[(2-dimethoxytiophosphoryl)-2-methylhydrazono]methyl\}-chromen-4-one (CH-3) and 2-amino-6-chloro-3[(2-hydroxyethyl)-hydrazonomethyl]-chromen-4-one (A$12)$, on lipid peroxidation and bFGF concentration in the HL-60 cells. Both of the studied compounds had a significant influence on bFGF and TBARS in ranges -137.20 $380.26 \%$ and $-81.66 \sim-28.68 \%$, respectively, in comparison with the control (counted as $0 \%$ ).
\end{abstract}

Key words: chromone, hydrazone, phosphorohydrazone, lipid peroxidation, bFGF, HL-60

Received: 11 February, 2013; revised: 24 May, 2013; accepted: 03 June, 2013; available on-line: 13 June, 2013

\section{INTRODUCTION}

During cancer transformation processes each cell loses its ability to control replications and obtain the values of cancer cells (Ścibior-Bentkowska \& Czeczot, 2009). The transformation of a healthy cell into a cancer cell is caused by the activation of proto-oncogenes and/or inactivation of suppressors and mutagenic genes. This process can be triggered by numerous factors including reactive oxygen species (ROS). It has been indicated that chronic, excessive ROS production can lead to oxidative stress, which has been observed in several hematopoietic malignancies including acute and chronic myeloid leukemia (AML and CML, respectively) (Sallmyr, Fan \& Rassool, 2008; Hole et al., 2011). However, yet it is not clear whether oxidative stress in leukemia contributes to the suppression or rather to the development, progression, or maintenance of these diseases.

Literature provides us with evidences that tumor-derived ROS may promote cell survival, migration, metastasis, and proliferation (Clerkin et al., 2008; Nishikawa, 2008; Maraldi et al., 2009; Naughton et al., 2009). Zhou et al. suggested that AML relapse is associated with an increase in ROS production (Zhou et al., 2010), therefore indicating the protective role of oxidative stress in leukemic cells. However, excessive ROS production leads to double- stranded DNA breaks and patients with AML and excessive ROS production caused by an internal tandem duplication of fms-like tyrosine kinase 3 (Flt3-ITD) exhibit poorer prognosis (Sallmyr et al., 2008). Therefore, drugs, which decrease the oxidative stress in leukemic cells, may appear beneficial.

Oxidative stress in cancer cells can be associated with its influence on cell membrane lipid peroxidation (LPO) (Kulbacka, 2009). LPO products modify physical properties of cell membranes, causing a decrease in biomembranes fluidity, which leads to cell destruction and organ damage (Gao et al., 2002). LPO can be screened and monitored in cells by measuring the level of thiobarbituric acid reactive substances (TBARS). Previous study recommends the TBARS assay as a good choice for measuring the levels of lipid peroxidation in secondary products, such as MDA, 2,4-decadienols, saturated aldehydes (Esterbauer \& Chjeeseman, 1994). It was indicated that MDA is detected in plasma of patients with chronic myeloid leukemia especially during its accelerated phase (Singh et al., 2009).

Cytokines and growth factors are produced in response to injuries and also act locally to modulate cell responses to vascular damage (Sahni et al., 1998). In particular, the basic fibroblast growth factor (bFGF) increases endothelial cell migration and proliferation, but also stimulates angiogenesis in vitro and in vivo, regulates the expression of proteolytic mediators of angiogenesis, including the urokinase receptor plasminogen activator (u-PAR), urokinase plasminogen activator (u-PA), and collagenase. After an injury, bFGF is released from vessel wall cells.

Recent evidence suggests that bone marrow neoangiogenesis plays an important role in the pathogenesis of associated marrow leukemia (Kulimova et al., 2006). Basic fibroblast growth factor can also act as an autocrine cytokine in those diseases. The receptors for VEGF (vascular endothelial growth factor), PDGF (platelet-derived growth factor), and bFGF are members of the split kinase domain family of receptor tyrosine kinases (RTK). Therefore, leukemia cells have receptors that specifically bind bFGF, which in turn stimulates their proliferation (Luizzo \& Moscatelli, 1996).

The chemical derivatives of various natural compounds of benzo- $\gamma$-pyrones possess an interesting biological property in vitro (Nunthanavanit et al., 2008; Huang et al., 2009; Amin et al., 2010) and in vivo (Di Braccio et al., 2003; Nawrot-Modranka et al., 2004; Nawrot-Modranka et al., 2006). It was earlier shown that chromone derivative, the 6-ethoxychromone-3-carbaldehyde benzoyl hy-

e-mail: marta.michalska@umed.lodz.pl

Abbreviations: AML, acute myeloid leukemia; bFGF, basic fibroblast growth factor; LPO, lipid peroxidation; MDA, malondialdehyde; ROS, reactive oxygen species; TBA, thiobarbituric acid; TBARS, thiobarbituric acid reactive substances 
drazone, has sufficiently scavenged the hydroxyl radical and superoxide anion in HL-60 and A-549 tumor cells (Wang et al., 2007). Similar results were described by another team for icariin (natural chromone derivative) treated erythrocytes (Liu et al., 2004).

Based on the results of our previous research on the HL-60 cell line (Lazarenkow et al., 2012), we choose two hydrazones of chromone to study their influence on bFGF and TBARS concentrations in human leukemia cells.

\section{MATERIALS AND METHODS}

The following compounds were investigated: 3 - $\{[(2$-dimethoxytiophosphoryl)-2-methylhydrazono $]-$ methyl $\}$-chromen-4-one (CH-3) and 2-amino-6-chloro-3[(2-hydroxyethyl)-hydrazonomethyl]-chromen-4-one (A12) (Fig. 1).

Cultivating and exposition of HL-60 cells on studied compounds. HL-60 cells were grown in agreement with our previous studies (Lazarenkow et al., 2012). After cultivating, the cells were counted $\left(6.5 \cdot 10^{6}\right)$ and exposed to A-12 or CH-3 in concentration of $1 \times I C_{50},(8.1 \pm 0.6$ and $36.1 \pm 2.8 \mu \mathrm{mol} / \mathrm{L}$, respectively) according to our previous findings (Lazarenkow et al., 2012). After 24 or 48 h of incubation, the cells were gathered, frozen, and keep at the temperature of $-80^{\circ} \mathrm{C}$ for further biochemical analysis. The control cells were treated in the same way but without the examined derivatives.

Determination of lipid peroxidation. After incubation, the cells were counted and $1 \cdot 10^{6}$ cells were diluted with ice cold $0.01 \mathrm{~mol} / \mathrm{L}$ phosphate buffer ( $\mathrm{pH}$ 7.4) containing $0.9 \% \mathrm{NaCl}$, sonicated three times (60 s, pause $90 \mathrm{~s}$, amplitude $30 \%$ ), and centrifuged at $10000 \times \mathrm{g}$ for $15 \mathrm{~min}$. The content of lipid peroxidation products in the supernatant was assayed as thiobarbituric acid reactive substances (TBARS) using the Yagi method (1976) with some modifications. Briefly, $1 \mathrm{~mL}$ of solution, containing $0.25 \%$ hydrochloric acid, $0.375 \%$ thiobarbituric acid (TBA), 15\% trichloroacetic acid, and $0.015 \%$ butylated hydroxytoluene was added to $100 \mu \mathrm{L}$ of supernatant. The samples were boiled for $30 \mathrm{~min}$ in tightly closed tubes. After cooling to $10^{\circ} \mathrm{C}, 2.5 \mathrm{~mL}$ of butanol was added to each tube. After intensive shaking the tubes were centrifuged at $3800 \times g$ for $10 \mathrm{~min}$. Finally, the upper solvent layer was removed and TBA-reactive substances were measured spectrofluorometrically using a luminescence spectrometer (LS-50, Perkin Elmer, Norwalk, USA) at an excited wavelength of $\lambda=515 \mathrm{~nm}$ and emission of $\lambda=546 \mathrm{~nm}$. The concentration of TBARS was expressed as equivalents of 1,1,3,3-tetraethoxypropane that was used as the standard. All measurements were represented as means \pm S.D. The statistical analysis was performed by ANOVA (analysis of variance) followed by the Shapiro-Wilk test. Statistical significance was set at $p \leq 0.05$.

Determination of bFGF concentration in the studied cell line. After incubation, cells were washed with $0.01 \mathrm{~mol} / \mathrm{L}$ phosphate buffer ( $\mathrm{pH} 7.4)$, containing $0.9 \% \mathrm{NaCl}$, sonicated three times (60 s, pause 90 $\mathrm{s}$, amplitude $30 \%$ ) and centrifuged $(1200 \mathrm{rpm}, 15 \mathrm{~min}$, $\left.4^{\circ} \mathrm{C}\right)$. Next, the supernatant was collected and assayed freshly for bFGF using the ELISA kit (Quantikine, R\&D System, USA). The assay was performed following the manufacturer's instructions. The results were read using the $\mathrm{BIO}-\mathrm{TEK} \mathrm{El}_{\mathrm{x}}-800$ spectrophotometer<smiles>COP(=S)(OC)N(C)/N=C/c1coc2ccccc2c1=O</smiles>

Figure 1. Structure of the studied compounds

apparatus at $\lambda=562 \mathrm{~nm}$. Final bFGF concentrations were calculated, using standard curve and described in $\mathrm{pg} / \mathrm{mL}$. The statistical calculations were prepared using the Stat-Soft Statistica 8.0 PL software. Statistical analysis was performed using $t$-test and Shapiro-Wilk test. Significance levels were set at $p<0.05$ for $t$-test and $p>0.05$ for Shapiro-Wilk test, respectively.

\section{RESULTS AND DISCUSSIONS}

\section{Lipid peroxidation assay}

Changes in TBARS levels are presented in Fig. 2. A $24 \mathrm{~h}$ incubation of HL-60 cells with $\mathrm{CH}-3$ and A-12 showed a marked reduction in the TBARS concentration $(p<0.05)$. However, further decline in TBARS level was observed only in case of the $\mathrm{CH}-3$ group (48 hours of incubation, $p<0.001)$, while in cells treated with A-12 the TBARS level increased. Nevertheless, the TBARS content in the A-12 group after $24 \mathrm{~h}$ of incubation was still lower than in the control. Our results also showed that $\mathrm{CH}-3$ significantly lowered the TBARS level in HL-60 cells at 24 hours of incubation when compared to the A-12 group $(p<0.05)$. It may therefore indicate a more potent lipid peroxidationlowering potential of CH-3 in HL-60 cells.

Previous study evidenced that membrane lipid peroxidation may trigger the release of cytochrome $c$ from the mitochondrial inner membrane and phosphatydylserine translocation which are critical events to the elicitation of apoptosis (Ma et al., 1999; Chiou et al., 2003). Decreasing of lipid peroxidation may indicate diminishing ROS generation under the influence of CH-3. Therefore, the lipid-lowering effect of CH-3 on HL-60 cells may be a possible explanation for the delay of HL-60 cell apoptosis observed in our previous report (Lazarenkow et al., 2012).

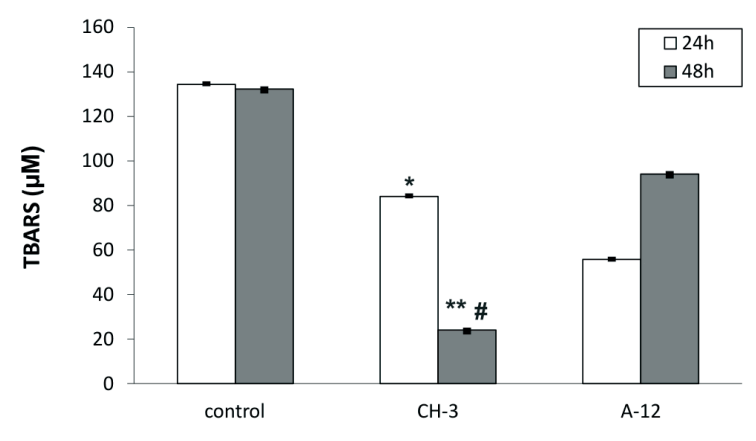

Figure 2. Changes in the level of TBARS in HL-60 cells after incubation with $\mathrm{CH}-3$ or $\mathrm{A}-12$ at 24 and 48 hours time.

The cells were treated with tested compounds at the concentration of $1 \times / C_{50}$. The control group consists of non-treated cells only. The results are presented as mean \pm S.D. ${ }^{*} p<0.05,{ }^{* *} p<0.001$ vs. control, $\# p<0.005$ vs. CH-3 $24 \mathrm{~h}$. 
Table 1. The influence of $\mathrm{CH}-3$ and A-12 on the concentration of bFGF in the HL-60 cell lines after 24 and 48 hours of incubation. Statistical analysis made with $t$-test and Shapiro-Wilk (S-W) test.

\begin{tabular}{|c|c|c|c|c|c|c|c|c|c|c|}
\hline Type & Time & & & & {$[\mathrm{pg} / \mathrm{ml}$} & & & & $t$-test & S-W \\
\hline of Probe & $\mathrm{h}$ & $x_{1}$ & $x_{2}$ & $x_{3}$ & $\mathrm{x}_{4}$ & $x_{5}$ & $\bar{x}$ & \pm S.D. & $p$ & $p$ \\
\hline Control & 24 & 4.69 & 4.83 & 4.80 & 4.84 & 4.39 & 4.710 & 0.189 & $6.15 \cdot 10^{-7}$ & 0.0543 \\
\hline Control & 48 & 10.90 & 11.90 & 10.57 & 10.46 & 10.11 & 10.848 & 0.683 & $3.82 \cdot 10^{-6}$ & 0.5988 \\
\hline$A-12$ & 24 & -1.72 & -1.70 & -1.78 & -1.76 & -1.80 & -1.752 & 0.042 & $7.53 \cdot 10^{-8}$ & 0.7540 \\
\hline$A-12$ & 48 & 6.48 & 6.30 & 6.29 & 6.50 & 7.00 & 6.514 & 0.289 & $9.24 \cdot 10^{-7}$ & 0.0998 \\
\hline $\mathrm{CH}-3$ & 24 & 22.60 & 22.3 & 23.10 & 22.30 & 22.80 & 22.620 & 0.342 & $1.25 \cdot 10^{-8}$ & 0.4642 \\
\hline $\mathrm{CH}-3$ & 48 & 14.90 & 14.86 & 14.60 & 14.30 & 14.34 & 14.600 & 0.281 & $3.28 \cdot 10^{-8}$ & 0.2750 \\
\hline
\end{tabular}

\section{Investigation of bFGF concentration in the studied cell lines}

In our experiment, the level of bFGF was significantly changed after 24 hours of incubation with both studied compounds, especially $\mathrm{CH}-3$ (the difference in action between those compounds is $243 \%$ ), while A-12 possessed more significant influence on the bFGF level after 48 hours $(|x|>5 \%$ in comparison with $\mathrm{CH}-3)$. This effect could be associated with inhibition of tyrosine phosphorylation and the mitogenactivated protein kinase pathway (Liekens et al., 1999; Lundin et al., 2003; Karam et al., 2012).

The results regarding A-12 effects on bFGF content after 24 hours of exposition showed similar negative values $(-1.752 \pm 0.042 \mathrm{pg} / \mathrm{mL}$, Table 1$)$. This indicated an overall lower concentration of bFGF in the HL-60 cell lines treated with A-12. It is possible that A-12 influences bFGF's metabolism or increases its releasing, however, this effect needs to be further analyzed. We also cannot exclude the possible interaction of A-12 with the ELISA kit components, although it is unlikely. All obtained statistical data are in agreement with our assumptions.

Figure 3 sums up the obtained results as it illustrates the percentage relative concentration of bFGF and TBARS in the samples in comparison with the control. Because this figure operates on relative high percentage values, the percentage deviations of these values are not visible on this scale; therefore, to make the Fig. 3 clearly readable, the deviation data was not included. Figure 3 exhibits the negative values of A-12 samples at 24 hours which were converted to $[-($ Control $+|\overline{\mathrm{x}}|)]$.

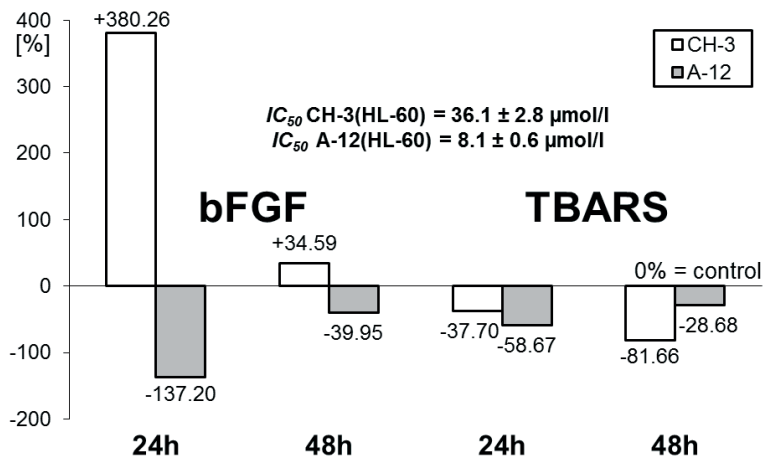

Figure 3. Percentage comparison of the influence of $\mathrm{CH}-3$ and A-12 on the concentration of bFGF in cells after 24 and 48 hours of incubation.

Both compounds were tested in $I C_{50}$ concentrations, described in our previous paper (Łazarenkow et al., 2012).

\section{CONCLUSIONS}

Both of the studied compounds (A-12 and $\mathrm{CH}-3$ ) had a significant influence on tested biochemical parameters. We observed an antagonism of their influence on the bFGF concentration in HL- 60 cells. A-12 proved to be more effective in decreasing TBARS level at $24 \mathrm{~h}$ of incubation while $\mathrm{CH}-3$ showed a long lasting lipid-lowering effect on HL-60 cells.

Reassuming, the studied hydrazone derivatives of benzo- $\gamma$-pyrones prove the purpose of further investigations regarding their influence on proliferative parameters and oxidative stress in leukemic cells.

\section{Acknowledgements}

We would like to acknowledge Marek Różalski and Urszula Krajewska from the Department of Pharmaceutical Biochemistry, Medical University of Lodz for the preparation of the cell culture.

This work was supported by the Medical University of Lodz (grants No 503/3-016-02/503-01 - NawrotModranka J, Lazarenkow A, 502-03/3-016-02/502-34002 - Łazarenkow A, 503/3-015-02/503-01 - Michalska M, Mirowski M and 503/0-079-03/503-01 - Gorąca A, Piechota-Polanczyk A).

\section{REFERENCES}

Amin R, Krammer B, Abdel-Kader N, Verwanger T, El-Ansary A (2010) Antibacterial effect of some benzopyrone derivatives. Eur J Med Chem 45: 372-378.

Chiou T, Chu S, Tzeng W (2003) Protection of cells from menadioneinduced apoptosis by inhibition of lipid peroxidation. Toxicology 191: 77-88.

Clerkin JS, Naughton R, Quiney C, Cotter TG (2008) Mechanisms of ROS modulated cell survival during carcinogenesis. Cancer Lett 266: 30-36.

Di Braccio M, Grossi G, Roma G, Marzano C, Baccichetti F, Simonato M, Bordin F (2003) Pyran derivatives. Part XXI. Antiproliferative and cytotoxic properties of novel $N$-substituted 4-aminocoumarins, their benzo-fused derivatives, and some related 2-aminochromones. Farmaco 58: 1083-1097.

Esterbauer H, Chjeeseman K (1994) Determination of aldehydic lipid peroxidation products: malonaldehyde and 4-hydroxynonenal. Methods Enzymol 186: 406-413.

Gao F, Yao C, Gao E, Mo Q, Yan W, McLaughlin R, Lopez B, Christopher T, Ma X (2002) Enhancement of glutathione cardioprotection by ascorbic acid in myocardial reperfusion injury. I Pharmacol Exp Ther 301: 543-550.

Hole PS, Darley RL, Tonks A (2011) Do reactive oxygen species play a role in myeloid leukemias? Blood 117: 5816-5826.

Huang W, Ding Y, Miao Y, Liu M, Li Y, Yang G (2009) Synthesis and antitumor activity of novel dithiocarbamate substituted chromones. Eur J Med Chem 44: 3687-3696.

Karam M, Lassarre C, Legay C, Ricort J (2012) Phosphatidylinositol 3-kinase and protein kinase D1 specifically cooperate to negatively 
regulate the insulin-like growth factor signaling pathway. Biochim Biophys Acta 1823: 558-569.

Kulbacka J, Saczko J, Chwiłkowska A (2009) Oxidative stress in cells damage processes. Pol Merk Lek 157: 44-47 (in Polish).

Kulimova E, Oelmann E, Bisping G, Kienast J, Mesters RM, Schwäble J, Hilberg F, Roth GJ, Munzert G, Stefanic M, Steffen B, Brandts C, Müller-Tidow C, Kolkmeyer A, Büchner T, Serve H, Berdel WE (2006) Growth inhibition and induction of apoptosis in acute myeloid leukemia cells by new indolinone derivatives targeting fibroblast growth factor, platelet-derived factor and vascular endothelial growth factor receptors. Mol Cancer Ther 5: 3105-3112.

Liekens S, Leali D, Neyts J, Esnouf R, Rusnati M, Dell'Era P, Maudgal P, De Clercq E, Presta M (1999) Modulation of fibroblast growth factor-2 receptor binding, signaling, and mitogenic activity by heparin-mimicking polysulfonated compounds. Mol Pharmacol 56: 204-213.

Liu Z, Luo X, Sun Y, Wu W, Liu C, Liu Z, Liu S (2004) The antioxidative effect of icariin in human erythrocytes against free-radicalinduced haemolysis. J Pharm Pharmacol 56: 1557-1562.

Luizzo JP, Moscatelli D (1996) Human leukemia cell lines bind basic fibroblast growth factor (bFGF) on FGF receptors and heparin sulfates: downmodulation of FGF receptors by phorbol ester. Blood 87: 245-255.

Lundin L, Rönnstrand L, Cross M, Hellberg C, Lindahl U, ClaessonWelsh L (2003) Differential tyrosine phosphorylation of fibroblast growth factor (FGF) receptor-1 and receptor proximal signal transduction in response to FGF-2 and heparin. Exp Cell Res 287: 190198.

Łazarenkow A, Nawrot-Modranka J, Brzezińska E, Krajewska U, Różalski M (2012) Synthesis, preliminary cytotoxicity evaluation of new 3-formylchromone hydrazones and phosphorohydrazone derivatives of coumarin and chromone. Med Chem Res 21: 1861-1868.

Ma Y, Ogino T, Kawabata T, Li J, Eguchi K, Okada S (1999) Cupric nitrilotriacetate-induced apoptosis in HL-60 cells: Association with lipid peroxidation, release of cytochrome $\mathrm{C}$ from mitochondria, and activation of caspase-3. Free Radic Biol Med 27: 227-233.

Maraldi T, Prata C, Vieceli Dalla Sega F, Calicetti C, Zambonin L, Fiorentini D, Hakim G (2009) NAD(P)H oxidase isoform Nox2 plays a prosurvival role in human leukaemia cells. Free Radic Res 43: 1-11.
Naughton R, Quiney C, Turner SD, Cotter TG (2009) Bcr-Abl-mediated redox regulation of the PI3K/AKT pathway. Leukemia 23: 1432-1440.

Nawrot-Modranka J, Ochocki J, Graczyk J (2004) Phosphorohydrazines of 4-oxo-4H-1-benzopyran and 1-benzopyran-2,4-dione exhibit antitumor activity against L1210 leukemia. Pharmazie 59: 731-732.

Nawrot-Modranka J, Nawrot E, Graczyk J (2006) In vivo antitumor, in vitro antibacterial activity and alkylating properties of phosphorohydrazone derivatives of coumarin and chromone. Eur J Med Chem 41: 1301-1309.

Nishikawa M (2008) Reactive oxygen species in tumor metastasis. Cancer Lett 266: 53-59.

Nunthanavanit P, Anthony NG, Johnston BF, Mackay SP, Ungwitayatorn J (2008) 3D-QSAR studies on chromone derivatives as HIV1 protease inhibitors: application of molecular field analysis. Arch Pharm Chem Life Sci 341: 357-364.

Sahni A, Odrljin T, Francis CW (1998) Binding of basic fibroblast growth factor to fibrinogen and fibrin. J Biol Chem 273: 7554-7559.

Sallmyr A, Fan J, Datta K, Kim K, Grosu D, Shapiro P, Small D, Rassool F (2008) Internal tandem duplication of FLT3 (FLT3/ITD) induces increased ROS production, DNA damage, and misrepair: implications for poor prognosis in AML. Blood 111: 3173-3182.

Sallmyr A, Fan J, Rassool FV (2008) Genomic instability in myeloid malignancies: increased reactive oxygen species (ROS). DNA double strand breaks (DSBs) and error-prone repair. Cancer Lett 270: 1-9.

Singh R, Tripathi A, Tripathi P, Singh S, Singh R, Ahmad R (2009) Studies on biomarkers for oxidative stress in patients with chronic myeloid leukemia. Hematol Oncol Stem Cell Ther 2: 285-288.

Ścibior-Bentkowska D, Czeczot H (2009) Cancer cells and oxidative stress. Postepy Hig Med Dosw 63: 58-72.

Wang B, Yang Z, Crewdson P, Wang D (2007) Synthesis, crystal structure and DNA-binding studies of the Ln(III) complex with 6-hydroxychromone-3-carbaldehyde benzoyl hydrazone. I Inorg Biochem 101: 1492-1504.

Yagi K (1976) A simple fluorometric assay for lipoperoxide in blood plasma. Biochem Med 15: 212-216.

Zhou F, Zhang W, Wei Y, Meng S, Bal G, Wang B, Yang H, Tian W, Meng X, Zang H, Chen S (2010) Involvement of oxidative stress in the relapse of acute myeloid leukemia. J Biol Chem 285: 1501015015. 